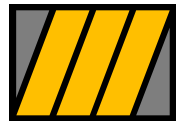

ESCUELA DE NEGOCIOS Universidad Torcuato Di Tella

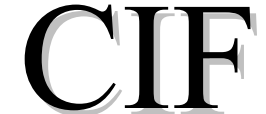

Centro de Investigación en Finanzas

Documento de Trabajo 11/2002

\title{
On the Endogeneity of Exchange Rate Regimes
}

Eduardo Levy Yeyati

Universidad Torcuato Di Tella

Federico Sturzenegger

Universidad Torcuato Di Tella

Iliana Regio

UCLA
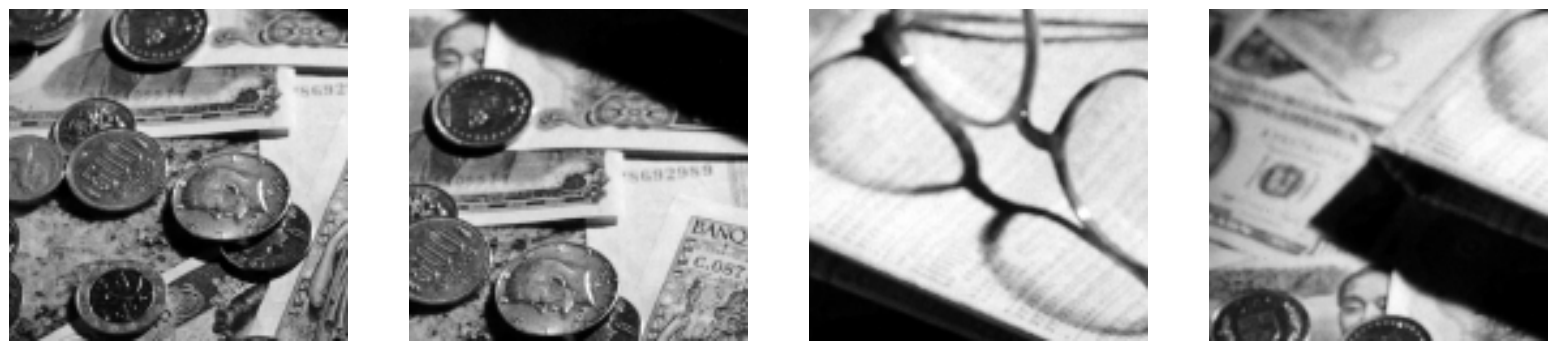

Miñones 2177, C1428ATG Buenos Aires • Tel: 4784.0080 interno 181 y 4787.9394 - Web site: www.utdt.edu/departamentos/empresarial/cif/cif.htm 


\title{
On the Endogeneity of Exchange Rate Regimes
}

\author{
Eduardo Levy-Yeyati, \\ Federico Sturzenegger, \\ and \\ Iliana Reggio ${ }^{\otimes}$
}

\begin{abstract}
The literature has identified at least five approaches to the determinants of the choice of exchange rate regimes: i) optimal currency area theory; ii) exchange rate policy and the absortion of real and nominal shocks; iii) exchange rate rules as a policy crutch in credibility-challenged economies; iv) the impossible trinity in light of increasing financial globalization; and v) the balance sheet exposure to exchange rate changes in financially dollarized economies. Using both a de facto and a de jure regime classification, we test the empirical relevance of these approaches simultaneously. We find overall empirical support for all of them, although their relative relevance varies substantially between industrial and non-industrial economies. We show that regime choices, as well as deviations between actual and reported policies, can be accurately predicted by a small number of economic and political characteristics of each country. When regimes are correctly characterized, they display no time trend, suggesting that the trends typically highlighted in the exchange rate regime debate can be traced back to the evolution of their natural determinants.
\end{abstract}

\footnotetext{
${ }^{\otimes}$ Eduardo Levy Yeyati and Federico Sturzenegger are with the Business School of Universidad Torcuato Di Tella, Iliana Reggio is with the University of California at Los Angeles. The authors wish to thank Luciana Monteverde for her outstanding research assistance and the CIF (Centro de Investigacion en Finanzas) of Universidad Torcuato Di Tella for support.
} 


\section{Introduction}

For open economies the choice of exchange rate regimes has always been a crucial policy decision. As a result, the relative merits of fixed versus flexible exchange rates have been the subject of continuous attention. The rage with fixed exchange rates prevalent in the first half of the 90s (in great part due to their presumed beneficial effects on inflation), drastically reverted after the stream of crises that started with the devaluation of the Mexican peso in 1994, which casted doubt on the sustainability of conventional pegs and other intermediate regimes. ${ }^{1}$ Indeed, as a result, a new consensus has been growing, both in policy and academic circles, around a bipolar view that poses the exchange rate debate largely in terms of a credibility vs. flexibility dilemma, contrasting the stabilizing effects of a superfixed regime (hence, the emphasis on currency boards and unilateral dollarization as commitment mechanisms) with the traditional Mundellian arguments in favor of full exchange rate flexibility. ${ }^{2}$

Yet much of the discussion (and most empirical literature) on the evolution and implications of different exchange rate regimes has tended to view the regime choice as a decision independent from country-specific characteristics and the regional and international situation at the moment the choice is being made. ${ }^{3}$ Such a "one-size-fits-all" approach seems at odds with both casual evidence and conventional wisdom, which would caution against a judgement on the relative merits and the economic implications of regimes that does not take into account the fact that regimes are themselves endogenous to the local and global economic contexts. ${ }^{4}$

Not that the endogeneity of exchange rate regimes has gone unnoticed in the economic literature, a large body of which has provided key insights on the potential determinants of the regime choice. But, to our knowledge, the empirical exploration of these determinants have been partial, focusing on a particular hypothesis or group of countries,

\footnotetext{
${ }^{1}$ The fall from grace of pegs is probably not independent from the increasing unwillingness of international financial institutions to foot the resources needed to sustain what they have tended to see as ultimately unsustainable exchange rates.

${ }^{2}$ On the bipolar view, see Fischer (2001), Levy Yeyati and Sturzenegger (2001a), and references therein. Examples of pro-fix arguments can be found in Calvo (1999, 2002), Hausmann (1999) and Hausmann et al. (2000). For pro-flex arguments, see, e.g., Chang and Velasco (2000).

${ }^{3}$ A notable exception is Obstfeld and Taylor (2002), who link the evolution of exchange rate arrangements to the historical phases of financial globalization, based on the Mundellian "impossible trinity" proposition that maintains that, under free capital mobility, no country can consistently pursue a fixed exchange rate and an autonomous monetary policy. Obstfeld and Taylor explain that, while capital mobility has prevailed at a time when monetary policy was subordinated to exchange rate stability (as in the gold standard), when countries attempted to use monetary policy to revice the economy in the interwar period, they had to impose controls to curtail capital movements. Inverting their argument, the current trend towards financial globalization, fueled by increased financial sophistication, by reducing the capacity to impose capital control, may have shifted the focus of the exchange rate debate. On the same point see Bordo and Flandreau (2001).

${ }^{4}$ For example, one can conceive reasons behind the well-documented fact that small open economies tend to be more prone to peg. Similarly, the move towards more flexible regimes in Mexico or many East Asian countries is better understood as the result of contemporaneous events in international financial markets rather than as a meditated change of heart on the part of the monetary authorities.
} 
without approaching the subject in a comprehensive model that encompasses all available candidates and individuals. ${ }^{5}$

This paper tries to fill this gap by discussing the determinants of the exchange rate regimes in such a comprehensive way. Thus, its contribution lies not only in the use of several alternative data sets, but, more importantly, on the nesting of what we regard as the main theoretical views on the determinants of exchange rate regimes in a common framework that allows us to test them jointly, unveiling the relative relevance of each one of them.

The paper introduces an additional novelty. In addition to the standard de jure classification of exchange rate regimes prepared by the IMF based on the periodic reports from the country's monetary authorities, it uses a de facto classification compiled by Levy Yeyati and Sturzenegger (2002), based on the actual behavior of exchange rates and exchange rate intervention.

Both classifications are used to test, simultaneously, the relevance of what we believe are the main five competing approaches to the choice of exchange rate regimes: i) the Optimal Currency Area (OCA) theory pioneered by Mundell (1961), which relates the choice of regime to the country's trade links, size and degree of openness; ii) the realnominal variability tradeoff dating back to the work of Poole (1970); iii) the view of pegs as "policy crutches" for governments lacking (nominal and institutional) credibility; iv) the impossible trinity view which stresses the role of financial integration and capital mobility as a factor limiting the effectiveness of pegs, ${ }^{7}$ and v) the implications of balance sheet effects on the costs of exchange rate variability in financially dollarized economies.

Our overall results indicate strong support for the OCA, policy crutch, impossible trinity and balance sheet effects, while the nominal-real tradeoff appears to be an important determinant only for industrial countries where other aspects are relatively less relevant. Reassuringly, results using the de jure classification, while less precise, lead to a similar diagnostic.

An examination of the mismatches between de jure and de facto regimes is consistent with the thrust of our basic results and what was to be expected from the literature. In particular, fear of floating (that is, reported floats that actually intervene to reduce exchange rate fluctuations) appears to be associated with the prevalence of balance sheets effects and nominal shocks. In turn, fear of pegging (that is, de facto pegs that choose not to commit explicitely to a fixed parity) increases with financial development (as countries are more exposed to speculative attacks) and with the prevalence of flexible regimes within the region (itself correlated with the probability of destabilizing exchange rate misalignments vis à vis the main trading partners).

\footnotetext{
${ }^{5}$ Many empirical papers study the determinants behind the choice of exchange rate regime. See, among others, Dreyer (1978), Heller (1978), Holden et al (1979), Melvin (1985) and, more recently, Collins (1996), Edwards (1996), Haussman et al (1999), Poirson (2001) and Rizzo (1998).

${ }^{6}$ To our knowledge, the only attempt to use a de facto classification to study the determinants of regime choices is Poirson (2001), who uses a variation of Levy Yeyati and Sturzenegger's approach to construct an exchange rate flexibility index.

${ }^{7}$ See, among many others, Rose (1996) and Fischer (2001).
} 
Finally, by recovering the time dummies used in the baseline regression, we can study whether the evolution of regimes display a particular time pattern beyond and above that associated with the set of controls. We find that the time dummies display no discernible pattern, suggesting that the trends typically highlighted in the recent exchange rate regime debate (towards the float extreme, or, in the case of the bipolar view, away from the middle ground) can be traced back to those embedded in the evolution of their natural determinants.

In sum, we conclude that a few fundamental characteristics of a country determine, to a great extent, the choice of exchange rate regime. Whatever the ultimate relevance of exchange rate regimes on economic performance is, ignoring or not fully understanding the role played by these variables and relying on fix-all recommendations may induce illadvised policies.

\section{The Theoretical Determinants of Exchange Rate Regimes}

As mentioned before, our exploration of the determinants of exchange rate regimes will be centered around five main approaches that we divide into two broad groups: traditional and modern. Traditional approaches that have long been part of the open economies macroeconomics toolkit include the theory of optimal currency areas (OCA), and the Mundell-Flemming-Dornbusch real vs. nominal shock approach. Modern takes on the exchange rate regime problem include the political economy view of pegs as policy crutches for weak governments with poor track records, the balance sheet view that stresses the costs of exchange rate fluctuations in financially dollarized economies, and the impossible trinity view that ties the costs of running a fix regime to the degree of capital mobility and financial integration. ${ }^{8}$ We review each of them in turn.

\section{II.a. Traditional Approaches}

\section{OCA theory}

The first group of factors potentially underpinning the choice of regime is related with geographical and trade characteristics identified by the theory of optimal currency areas. This approach to the fix vs. float dilemma weights the trade and welfare gains from a stable exchange rate vis à vis the rest of the world (or, more precisely, the country's main trade partners) against the benefits of exchange rate flexibility as a shock adjuster in the presence of nominal rigidities.

According to this argument, the country characteristics that favor a more stable (or fixed) exchange rate are: i) openness, which enhances trade gains derived from stable bilateral exchange rates, ii) smallness, through its effect on openness, given the usually higher propensity of small economies to trade internationally, and iii) geographical concentration of a country's trade, which increases the gains from pegging the currency

\footnotetext{
${ }^{8}$ As noted below, the impossible trinity concept dates back at least to the work of Mundell in the 1960s. However, the argument that conventional middle-of-the-ground pegs have become increasingly costly due to growing capital mobility in the post Bretton-Woods period is relatively recent.
} 
to that of the main trading partner ${ }^{9}$. As noted, OCA theory suggests that the sign of the relationship between these determinants and the propensity to fix should be positive in all cases.

In order to test this hypothesis we relate the exchange rate regime to two different measures of size, namely, physical size, measured as land area, (AREA) and economic size (SIZE), measured as the country's GDP relative to that of the US, and we measure openness by using the lagged GDP share of exports plus imports (OPEN1). ${ }^{10}$ In order to measure geographical concentration we use the lagged share of exports to the major partner (SHTRADE1).

Regional exchange rate policy coordination is also a relevant component of the OCA story. Everything else equal, the more fixed are exchange rate arrangements in the region (against the regional reference currency), the larger the trade-related cost of exchange rate variability. On the other hand, successive competitive devaluations increase the incentives of the remaining pegs to adjust accordingly (by realigning the exchange rate or directly floating the home currency). This suggests that the regime of individual countries should be correlated to the average regime of its main trading partners. A large literature that stresses the negative correlation between exchange rate variability and trade warns us against the use of a trade-weighted regime average. Instead, we use the neighbors' average regime (LYSAVG) as a proxy for bilateral exchange rate volatility vis à vis the main trade partners. ${ }^{11} \mathrm{We}$ expect that a higher number of pegs in the region increase the attractiveness of fixing.

\section{Regimes as Shock Absorbers (Nominal vs. Real Tradeoffs)}

From the traditional Mundell-Flemming-Dornbusch framework we obtain the familiar argument that, in order to minimize output fluctuations, fixed (flexible) exchange rates are to be preferred if nominal (real) shocks are the main source of disturbance in the economy. ${ }^{12}$ As a result, one should expect that the choice of exchange rate regime should depend, to a certain extent, on the importance of real relative to monetary shocks. For example, high volatility of terms of trade, or other external shocks, would provide a rationale for a float. ${ }^{13}$ Moreover, as real shocks become increasingly important due to

\footnotetext{
${ }^{9}$ Geographical concentration of a country's trade is expected to be positively related with the propensity to fix, since when a country's trade is concentrated in one major partner there are more benefits of pegging to the currency of that partner. This criterion seems to apply both to the European countries coordinating their exchange rates around the DM prior to EMU, as well as to countries in the accession list to EMU.

Similarly, many authors have highlighted the propensity of Central American countries to peg to the US dollar based on their important trade links. Alternatively, opponents to the Argentina currency board have flagged the inherent inconsistency of the peg in light of the Argentina's diversified trade partners.

${ }^{10}$ We used lagged oppeness to minimize potential endogeneity worries. The use of Frankel and Romer's (1999) measure of openness yields similar results at the cost of fewer observations. We come back to the issue of endogeneity below.

${ }^{11}$ Note that the argument would indicate that, if most US neighbors tend to peg to the dollar, any individual neighbor would be tempted to do so, despite the fact that the US floats its currency. Hence, reference currency countries are excluded from the computation of this variable,

${ }^{12}$ In both cases, given that prices tend to be more rigid to downward adjustment, the adjustment period is likely to be particularly long and taxing in the event of an adverse shock, the more so the less flexible domestic prices are.

${ }^{13}$ Haussman et al (1999), Lane (1995), and Frieden et al (2000) provide empirical evidence suggesting that, contrary to what could be expected, variability on terms of trade is positively related with the probability
} 
growing trade flows and capital market integration (alternatively, as monetary shocks or inflation concerns become less of a priority) one should expect to see a trend towards more flexible regimes.

To measure the importance of shocks on exchange rate regimes we include three variables to proxy for real aggregate demand shocks: the volatility of terms of trade, adjusted by openness to capture the relative importance of terms of trade shocks (VOLEXT), the volatility in the government consumption to GDP ratio (VOLGOV5), and the volatility in the investment to GDP ratio (VOLINV5). As a proxy for nominal disturbances we use the volatility of money velocity (VOLVELO5). All volatilities are measured as the standard deviation of annual values over the previous five years.

\section{II.b Modern Approaches to Exchange Rate Determination}

\section{The "policy crutch" approach}

A large strand of literature has emphasized the credibility gains of adopting a peg regime. In particular, it has been argued that governments with a low inflation bias but low institutional credibility facing the uphill task of convincing the public of their commitment with nominal stability may adopt a peg as a "policy crutch" to tame inflationary expectations. ${ }^{14}$ Thus, intimately related to the "policy crutch" approach is the link between institutional (and, in particular, government) strength and the exchange rate regime. As the argument goes, weak governments that are more vulnerable to "expansionary pressures" or "fiscal voracity" (i.e., pressures from fiscal groups with the power to extract fiscal transfers in times of windfall $)^{15}$ may choose to use a peg as way to fend off these pressures.

We include three political variables to control for the strength of the government. Firsty, we measure strength directly as the fraction of seats held in congress by the government party or coalition (MAJ). A larger majority implies a stronger government that, according to the policy crutch argument, will be in a better position to implement a floating regime without being taken hostage by interest groups. ${ }^{16}$ Accordingly, we expect the corresponding coefficient to be negative.

Secondly, the years the incumbent administration has been in office (YRSOFF). We expect this variable to be positively correlated with the propensity to peg, as it may be an inverse measure of its capacity to impose executive decision on the other powers. In short

that a country select a peg. Haussman et al (1999) propose an explanation for this results. They argue that "fixed exchange rate regimes should result in deeper financial markets, which should be particularly important in economies facing important terms of trade shocks".

${ }^{14}$ Hence, the usual association of this type of arguments in the literature with a "credibility" approach. Strictly speaking, this policy crutch does not achieve monetary credibility but rather presumes the lack of it and, by limiting the discretion of the policy maker, shies away from a costly credibility building process only achievable through a successful implementation of a discretionary policy. However, it may help pave the road to achieve fiscal credibility.

${ }^{15}$ See Tornell and Lane (1999).

${ }^{16}$ The underlying assumption is, of course, that representatives of the same party tend to vote together. 
we use the years in office as a proxy for the natural process of wearing off of any government.

Thirdly, we use a Herfindahl index of political parties, defined as the sum of the squared seat shares of all parties in the government. The sign of the link between this variable and the strength of the government is not straightforward. In some setups, such as those collective action problems studied by Olson $(1982,1993)$ more atomization of political players implies a worsening of common pool problems leading to even larger incentives to extract from the common resources and therefore to even more suboptimal policies. In such specification a lower value of the herfindal should lead to a higher propensity to peg. Alternatively, "voracity effect" stories, such as that in Tornell and Lane (1999) carry the opposite conclusion. As the number of players increases each group must reduce its appropriation rate to keep players within the formal economy (where their rents can be extracted) thus reducing the distortionary effects of redistributive policies. Thus, higher concentration, associated to stiffer political competition, should increase the propensity to fix. ${ }^{17}$ At any rate, the relation between political concentration and weakness of the government is non-monotonic. As Tornell and Lane (1999) point out, it is only when there is more than one party involved when the voracity effect kicks in. ${ }^{18}$

Finally, we exploit an alternative political economy argument than associates short-run economic performance with the exchange rate regime. More precisely, countries that have experienced a contraction in recent years are likely to generate stronger political pressure to inflate in order to achieve more rapid growth (and higher inflation expectations in the process), and may be prone to peg in order to fend off these pressures or reduce the inflation bias. ${ }^{19}$ To control for the temptation to inflate during recessions (which should be positively associated to the propensity to fix) we use a dummy (DUMCI1) that equals one whenever the growth rate in the preceding period is above the country's long-run growth rate. We expect the coefficient for this variable to be negative.

\section{Impossible trinity}

A key ingredient of the textbook Mundell-Fleming-Dornbusch framework is the assumption of perfect capital mobility that implies international interest rate arbitrage across countries in the form of the uncovered interest parity. From this framework it follows that monetary policies in open economies cannot be aimed both at maintaining stable exchange rates and smoothing cyclical output fluctuations due to real shocks in the presence of capital mobility. This is usually referred to as the "impossible trinity": the fact that policy makers can choose at most two out the three vortexes of the trinity: capital mobility, fixed exchange rates or monetary policy.

In line with this, it has been argued that, as financial globalization deepened in the last decades, monetary policy became increasingly at odds with fixed exchange rates. This

\footnotetext{
${ }^{17}$ In particular, the Herfindahl index tends to increase for bipartisan (or highly pollarized) governments.

${ }^{18}$ Many additional political variables were tested and found not to be significant, at the cost of losing a number of observations.

${ }^{19}$ See Edwards (1996). Again, the argument, which assumes that the government does not share the expansionary preferences of its constituency, can cut both ways: The government may be tempted to inflate after a protracted recession, abandoning the restrictive peg. As will be shown below, the sign of this variable differs between industrial and non-industrial countries.
} 
argument underscores the so-called "bipolar view" of exchange rate regimes, according to which increased capital mobility has made intermediate regimes less viable in (financially open) industrial and emerging economies. ${ }^{20}$ In addition, a rapid process of financial deepening and innovation (which typically has advanced pari passu with financial integration with international capital markets) has gradually reduced the effectiveness of capital controls, with the same consequences in terms of the monetary policy-exchange rate stability dilemma.

We assess the empirical relevance of the impossible trinity approach in different ways. First, we include a dummy for emerging and industrial countries (FINDEV), which we take as a proxy for financial depht and sophistication. We also control for the ratio of quasi money over money (QMM1, lagged to reduce the potential endogeneity of financial development) as an alternative proxy for the degree of domestic financial depth. ${ }^{21}$ In line with the impossible trinity view, we expect both variable to be associated with a lower propensity to peg.

\section{Financial Dollarization and Balance Sheet Effects}

Recent literature (most notably, Calvo, 1999 and 2000) has noted that balance sheet effects in financially dollarized economies may be critical to the choice of exchange rate regimes. In particular, countries with important (private or public) foreign liabilities may be more prone to fix (either de jure or de facto) due to the inherent currency imbalance and the deleterious impact of sharp nominal depreciation of the currency on the solvency of financial institutions. ${ }^{22}$

While there is no readily available measure of financial dollarization for a broad sample of countries, it can be proxied by the lagged ratio of foreign liabilities in the domestic financial sector, relative to money stocks (FLM1). ${ }^{23}$ According to this hypothesis we should expect higher liability dollarization to be positively associated with the probability of choosing a peg.

\section{Empirical Analysis}

The objective of this paper is to test the hypotheses presented in the previous section in a unified framework to assess the relative importance of each one of them. We run pooled

\footnotetext{
${ }^{20}$ See, e.g., Fischer (2001). The point has been raised earlier by Quirk (1994), among others.

${ }^{21}$ Some authors have argued that nominal (and, in particular, exchange rate stability) induces a process of financial deepening.

${ }^{22}$ It has to be noted that, while the real exchange rate adjustment in the event of a negative external shock cannot be avoided by the sustainement of a peg, the downward rigidity of prices may postpone the process over time, preventing a financial collapse. In addition, a nominal adjustment of the exchange rate is usually accompanied by an exchange rate overshooting that can only reinforce the negative financial implications.

${ }^{23}$ Kaminski and Schmukler's (2001) capital controls index, a natural control for the impossible trinity hypothesis, proved not to be significantly correlated with the regime choice, possibly due to the fact that it covers only 28 countries. Alternative measures of financial dollarization (such Ize and Levy Yeyati's (2000) dollarization ratio or Hausmann et al's (2000) ability to pay measures, cover only a very limited number of countries.
} 
logit regressions for an unbalanced panel data set of 183 countries over the post-Bretton Woods period (1974-1997) ${ }^{24}$ on the set of controls discussed in the previous section.

Our primary interest is to examine the relevance of different analytical approaches to the regime choice problem rather than the significance of individual variables. On the other hand, variables within each explanatory group may be highly correlated with each other. Accordingly, we focus the discussion on the joint relevance of each group of variables. ${ }^{25}$

Table 1, column (i), shows our baseline specification. Our dependent variable is a de facto fix dummy (LYSFIX) that takes a value of one if a country is classified as a de facto fix and zero otherwise. ${ }^{26}$ As can be seen, four out of the five groups of explanatory variables described above are found to be in line with our priors. In those cases, all variables display the expected sign and are jointly (and most of them individually) significant. The only exception are those regressors associated to the nominal-real tradeoff, which are patently irrelevant: While the signs are as expected, the variables are neither individually nor jointly significant.

Note that the results for the seem to support the view that pegs are associated to weaker governments. In particular, the signs of the coefficients for the Herfindahl index provide support to the "voracity effect" argument. On the other hand, note that FINDEV could also be considered as a proxy for capital liberalization, in which case the negative coefficient for this variable could be interpreted as indicating that greater capital mobility increases the probability of choosing a float.

Overall, the model displays a good level of accuracy in predicting actual regimes. It correctly identifies $71 \%$ of fixes and $74 \%$ of non fixers thus showing significant predictive power. $^{27}$

Columns (ii) and (iii) show the same baseline specification but splitting the sample into industrial and non-industrial countries, revealing some notable differences between the two. For the industrial sample, while all the nominal-real tradeoff variables have now the correct sign and are statistically significant, both impossible trinity and balance sheet effects lose their explanatory power. On the other hand, neighbors' average regime is no longer significant. These results indicate that industrial countries' exchange rate policy is not constrained by financial variables. Indeed, the temptation to inflate dummy reverses its sign, suggesting that countries undergoing a recession tend to adopt more flexible exchange rate policies to revive the economy. In turn, this increased independence leads to a more relevant role of the exchange rate as shock absorber, as captured by the nominal-real tradeoff. Political variables appear to be slightly weaker, but their overall significance remains high.

\footnotetext{
${ }^{24}$ Political variables are not available after 1997.

${ }^{25} \mathrm{P}$-values corresponding to the joint Wald tests for each group are presented at the bottom.

${ }^{26}$ The tables also report two measures of goodness of fit: the pseudo R2 (pseudoR2 $=1-\mathrm{L} / \mathrm{L}_{0}$ where $\mathrm{L}$ is the likelihood under the original model and $\mathrm{L}_{0}$ the likelihood value for a model with only a constant) and a Wald test of joint significance of the model.

${ }^{27}$ On the other hand, the Chow test yields a Chi-square value of 400, thus strongly rejecting the hypothesis that the specification is nonsignificant.
} 
The subsample of non-industrial countries (column iii) basically replicates the results for the full sample, although OCA variables appear to be somewhat weaker than for industrial economies.

One could argue that in the 90s, characterized by increasing financial liberalization and globalization, impossible trinity variables took over other explanatory factors, particularly in non-industrial economies. To explore this hypothesis, in columns iv and $\mathrm{v}$ we rerun the baseline specification splitting the sample in two periods: 1974-1980 and 1981-1990. We find no significant difference in the influence of each group of variables. Similarly, the main results hold when the test is restricted to low income (less developed) countries. (column vi).

Table 2, replicates the previous tests using the IMF-based de jure classification. ${ }^{28}$ As expected, while the results are less satisfactory than for the de facto classification, the main messages remain unaltered. OCA theory variables are still significant and of the correct sign, and so is the effect of the remaining variables. ${ }^{29}$ The salient exception is the variability of money velocity, which is significant and negative, contradicting our prior.

The apparent differences between the results derived from each classification bears the question of whether and to what extent our findings are driven by a particular classification criterion. However, a simple and rather crude test shows that the de jure approach yields basically the same results once obviously misclassified observations are excluded. To do that, we restrict the de jure fix group to relatively uncontroversial cases, defined as those for which the average monthly variation of the nominal exchange rate does not exceed $0.1 \% .{ }^{30}$ Once misclassified fixes (146 out of 1122 observations) are grouped with non-fixes, most of the original results reappear. In particular, the coefficient for the velocity variable is no longer significant, and the financial dollarization variables are again significantly correlated with the propensity to peg.

\section{Global Trends}

Our empirical specification allows for time effects through the inclusion of yearly dummies. Figure 1 shows the values for the yearly dummies throughout our sample both for our baseline specification based on the de jure classification, as well as for the specification using the IMF's de jure classification.

The value of these dummies can be interpreted as the impact of common global trends or changes in global conditions on the choice of regime. As can be seen, there is no identifiable pattern when using the de facto classification, indicating that our set of determinants capture most of the relevant factors underpinning exchange rate choices. However when using the IMF classification, we find that global conditions appear to suggest a higher propensity to float. This result is consistent with the fact that, while the late 1970s and 1980s were plagued by fixed but frequently realigned (or collapsed) regimes, during the 90 s (partly as a result of that) an increasing number of countries that

\footnotetext{
${ }^{28}$ For the sake of comparison, the IMF regression includes only those observations that are also classified under the de facto methodology. If we do not restrict the sample, the results are very similar with the difference that the SIZE coefficient becomes significantly negative.

${ }^{29}$ Some individual variables display the wrong sign, although in those cases they cease to be significant.

${ }^{30}$ Alternative (and reasonable low) cut-off points yield identical results.
} 
reported flexible regimes tend to behave in practice closer to a peg (a phenomenon usually referred to as "fear of floating"). ${ }^{31}$

To illustrate this bias, we recovered the time trend that results from rerunning the regression using the "revised" de jure classification based on uncontroversial pegs. As can be seen, while the time trend still exhibits a downward trend, its shape follows the de facto trend much more closely.

\section{Extensions and robustness checks}

Our baseline specification included what we believe are the most essential variables that the theory has identified as being related to exchange rate regimes. However, the interpretation of many of these variables is not free of complications. In particular in this section we want to discuss two extensions: further strengthening the scope of political variables and evaluating potential endogeneity problems.

\section{Policy Crutch vs. Sustainability}

To be sure, the literature does not provide an unambiguous answer regarding the sign of the link between political strength and regimes. Indeed, our policy crutch effect can be easily reversed: Weak or unstable governments could be associated with larger deficits (or lower ability to reduce it, if needed), suggesting that a peg could be more difficult to sustain. This is particularly true in the presence of wars or civil unrest, ${ }^{32}$ but could be extended to episodes of political turmoil.

More in general, this "sustainability effect" would associate a weaker government with the collapse of existing pegs or the inability to launch a credible one, thus finding government strength positively correlated with pegs and not the other way around. For example, the fact that the output cycle variable does not come in significant may be a reflection of this tradeoff between commitment and sustainability, as one could argue that a recession may fuel political pressures in favor of a floating regime. ${ }^{33}$ More in general, if by this argument pegs under weak governments are less likely to be successful, then our estimates for the political strength variables may be biased downward.

More controversial is the interpretation of the link of the exchange rate regime and the inflation rate. One could argue, following Edwards (1996) and Frieden et al (2000), that countries with moderate to high inflation and (partly as a result of this) low credibility on the inflation front have incentives to use the exchange rate as an anchor (as witness the experiences with diverse tablitas in the 80 s or, more recently, the Argentine currency board). Thus, the choice of a peg as a policy crutch may be associated with previous failed attempts at lowering inflation (i.e., with a history of high inflation prior to the

\footnotetext{
31 Thus, the sign of the de facto-de jure mismatch tends to be correlated with a time trend. See Levy Yeyati and Sturzenegger (2002) for an empirical discussion of this point.

${ }^{32}$ However, a qualitative index of civil wars and political assesinations was found not to be significant when added to the baseline.

${ }^{33}$ Note that this implicitely assumes the convetional wisdom view of devaluations as expansionary, a fact for which the empirical evidence is rather mixed.
} 
choice of the peg) ${ }^{34}$ However, persistent high inflation creates pressures on the exchange rate market that may force monetary authorities to float (either voluntarily or as a consequence of a currency crisis). Thus, a negative inflation-exchange rate rigidity correlation suffers from a potential identification problem, and even the relationship itself is under question.

There is no easy option to solve this problem, but there are several partial ways to address it. On the one hand, it is reasonable to assume that the incidence of past inflation on the current propensity to peg follows a nonlinear relationship, increasing as inflation reaches higher (and more unmanageable) levels. ${ }^{35}$ Accordingly, it is useful to differentiate moderate from high inflation (and hyperinflation) episodes, as the latter have typically shown a stronger real effect and, as a result, have given way to rapid policy reactions.

In light of the above, to control for the sustainability of the peg, we add to our baseline specification the log of the inflation rate (INF1), ${ }^{36}$ as well as a dummy for high inflation (defined as an annual inflation rate exceeding $150 \%$, HIGH1), both lagged one period to reduce endogeneity. While we do not have a prior regarding the net effect of inflation per se, we expect a high inflation to increase the propensity to peg and a moderate inflation to increase the pressures to float.

An additional control for sustainability is drawn from a number of papers that have emphasized the role of international reserves as "life jackets" for emerging markets prone to suffer sudden reversals in the demand for local assets. ${ }^{37}$ According to this line of reasoning, a high level of reserves is often perceived as a necessary condition for the credibility and sustainability of a peg in developing economies, as they function as a standard insurance mechanism, deterring currency speculation or reducing the incidence of self-fulfilling currency runs. Accordingly, we include (lagged) international reserves relative to base money (RESBASE1), which we expect to be positively correlated with the probability of a country adopting (and maintaining) a peg.

The results are reported in Table 3 (baseline results are reproduced for comparison). Columns (i) and (ii) indicate that while past inflation is generally negatively correlated with the propensity to peg (suggesting that chronic inflation renders the peg ultimately unsustainable), a high inflation episode increases the probability of pegging, a link consistent with the policy crutch view of a peg as a last resort shortcut to nominal stability. In turn, the reserves variable is significantly and positively correlated with the propensity to peg, in line with the sustainability argument.

Thus, factors associated with the capacity of the government to defend the regime seem to exert a non-neglegible influence on the probability of having a peg at any point in time, suggesting that the regime is not only determined by choice but it may also be forced by the circumstances. However, controlling for sustainability of the regime leaves the political variables virtually unaffected, confirming the underlying mechanism by which

\footnotetext{
${ }^{34}$ There is empirical evidence that (long-lasting) pegs have been successful at reducing inflation. See, among others, Ghosh et al. (1997) and Levy Yeyati and Sturzenegger (2001b).

${ }^{35}$ The nonlinear effect of inflation on real variables has been documented in Sarel (1995).

${ }^{36}$ We use INF $1=\log \left(1+\pi_{t-1}\right)$.

${ }^{37}$ Both phenomena are thoroughly discussed by Calvo (1999), and Hausmann et al. (2000), among others.
} 
they affect the exchange rate regime, namely, that weaker governments with a dearer need of a credibility enhancing mechanism tend to favor fixed regimes.

\section{Endogeneity}

Our regressions have shown the relevance of a number of variables on the choice of regime. However, while most of these variables are not subject to endogeneity (size, area, political fundamentals and the volatility measures), the significance of some of them may be reflecting a possible reverse causality, as there is ground to think that, to some extent, they may be influenced by the exchange rate policy.

Take for example, the inflation rate that we discussed above. As documented in Ghosh et al (1997, and 2002) for de jure regimes and in Levy Yeyati and Sturzenegger (2001b) for de facto regimes, fixed exchange rates are known to lead to lower inflation rates. In order to control for this endogeneity factor we rerun in Table 4 the regression of column iv of Table 3, but measuring inflation now as the average inflation of the previous three years. Such measure should be substantially less influenced by endogeneity problems, and, as expected, the result remains, but weakens substantially.

Regarding the measures of openness and concentration of trade, it is important to note that the literature offers an alternatively story for the openness-exchange rate regime connection: Exchange rate stability (such as that provided by a peg) by reducing bilateral exchange rate volatility, may foster trade and, in turn, openness and concentration of trade. Thus, a positive association between openness and fixed exchange rates may reflect the reverse causality. Empirical studies supporting this hypothesis include Rose (1999), Rose and Frankel (2002), Rose and Glick (2002), and Rose and Van Wincoop (2001) . ${ }^{38}$ In order to control for this, we rerun in column ii our baseline specification using the initial values (those corresponding to year 1974) for concentration of trade (SHTRADE1) and openness (OPEN1). As can be seen both variables come in significantly with the expected signs and do not alter the other results.

Financial development has also been associated to exchange rate regimes. The argument is that the fixing of the exchange rate by reducing exchange rate volatility may foster financial development. However if the correlation between our measures of financial development and the exchange rate regime would be due to this reverse causality then we should expect a positive relation between financial development variables and pegged exchange rate regimes. Yet we find exactly the opposite result, indicating that, if such endogeneity problem is present, it is more than offset by the effect of financial development on the choice of regime.

Another potential concern is associated with the omission of relevant variables that are in turn correlated with the included regressors, therefore leading to spurious results. The most general way to control for (country-specific) omitted variables is by introducing country fixed effects in the regression that control for all those excluded factors that may be correlated with the right-hand side variables. Unfortunately, the introduction of fixed effects in our case has several drawbacks. On the one hand, by restricting information to within-country variability, it limits dramatically the usefulness of the data. And, as long

${ }^{38}$ See also the criticism in Persson (2001). 
as we are interested in the long-run determinants of regime choices, we do not want to discard the cross-country comparison of time-invariant pegs and floats (between-country variability). With fixed effects, this cross-country result is lost, as the logit estimation uses the fixed effect to match the probability of the observed outcome for that country regardless of the coefficients on the other variables thus dumping all variables without within-country volatility and all data for countries for which the chosen regime does not change. This notwithstanding, we report in column (iii) the estimates from a fixed effect estimation of the baseline specification. As can be seen, most results remain unchanged. The only relevant discrepancy is in the variables associated with the nominal-real tradeoff, which, although jointly significant, do not have the expected sign. Overall, however, the estimation is in line with our previous results.

\section{Fear of pegging and fear of floating}

Calvo and Reinhart (2002) define fear of floating as de jure floaters that intervened in the market to smooth the fluctuations of the nominal rate. Paraphrasing them, Levy-Yeyati and Sturzenegger (2002) define fear of pegging as having a de facto peg but claiming another regime. Fear of floating is associated with the objective of limiting the variability of the exchange rate in a globalized financial environment, due to the combination of substantial external volatility, balance sheet effects and a large pass-through coefficient. Similarly, fear of pegging can be interpreted as a way of reducing the risks of speculative attacks on conventional pegs. In particular, as the latter gained a bad reputation after the succession of collapses in the late 1990s, countries that, for whatever reasons target the exchange rate may report a managed float as a way to avoid a commitment with a fixed parity and the reputational cost of being unable to defend it.

Table 5 shows how our five group of regime determinants fare for the cases of fear of floating and fear of pegging. For the former, we restrict our universe to de jure floats. The results should then be interpreted as the influence of our controls on the propensity to peg de facto within the group of reported floaters. In turn, to explore the determinants of fear of pegging we focus on the propensity of actual fixers not to report a fix. Thus, our dependent variable is a de jure non-fix dummy over the de facto fix sample. Our regressors are the same as in our baseline specification. Our conjecture is that our choice set of regime determinants should also account for the numerous deviations between reported and actual regimes.

Indeed, we find that fear of floating depends critically on a few variables, in line with our priors. In particular, column (i) shows that the presence of fear of floating is significantly associated to balance sheet effects, and to monetary shocks that are itself associated with sharp changes in the nominal exchange rate. On the other hand we find that small open economies (characterized by a larger pass-through coefficient) are more prone to exhibit fear of floating as suggested by the negative coefficient on AREA and positive coefficient on OPEN1 (albeit not significant). Somewhat surprisingly, however, political variables do not seem to play a significant role. 
Regarding fear of pegging, we find that it is correlated with the prevalence of de facto floats in the region. This is consistent with the evidence that exchange rate variability in neighbouring countries is often the trigger to speculative attacks on the home currency. Thus, frequently changing bilateral exchange rates with the main trade partners opens a vulnerability that authorities may want to avoid by preserving the option to modify the exchange rate without major regime disruptions. Fear of pegging is also correlated with trade diversification, an alternative measure of exposure to external shocks that affect the exchange rate vis à vis the peg currency.

On the other hand, fear of pegging is associated with financially developed economies with deep financial markets that are less easily controlled, in line with the view of that economies shy away from explicit commitments to a fixed parity when they are more prone to successful speculative attacks.

Political variables also provide insights as to why there is fear of pegging. On the one hand the negative sign of YRSOFF indicates that political weakness is associated to the need to state a fixed regime, a result which is in line with the higher prevalence of fixers among long-tenured governments. On the other, the negative sign on MAJ suggests that the stronger governments are more prone to report a peg when they are running it. Thus, the evidence is not conclusive about the link beween political strength and fear of pegging, which is reflected in the lack of joint significance for the group.

\section{Conclusions}

The evidence presented in this paper indicates that the choice of exchange rate regimes can be traced back to a relatively tight group of political, geographical and financial variables that, reassuringly, closely reflect underlying theories of regime determination. Not surprisingly, some views on exchange rate regimes are more appropriate for some countries than for others, depending the country's characteristics.

Understanding the role played by country-specific factors in the determination of exchange rate regimes is essential to assess the convenience and the ultimate success of any attempt to induce a country to adopt a float or a fix in a given context. In some cases, the recommendation may suggest a regime the country is naturally prone to choose. But if the country's fundamentals suggest otherwise, an unqualified advice is likely to lead to a regime reversal down the road. 


\section{$\underline{\text { References }}$}

Bordo, Michael and Marc Flandreau (2001). Core, Periphery ,Exchange rate regimes, and globalization. NBER WP N ${ }^{\circ} 8584$.

Calvo, Guillermo (1999) Fixed versus Flexible Exchange Rates: Preliminaries of a Turnof-Millennium Rematch, mimeo University of Maryland.

Calvo, Guillermo (2001).Capital Markets and the Exchange rate: with special reference to the dollarization debate in Latin America. Journal of Money, Credit and Banking, vol 33, number2, part 2.

Calvo, Guillermo and Carmen Reinhart (2002) Fear of Floating.Quarterly Journal of Economics, Vol. 117, Issue 2, pp. 379-408.

Chang Roberto, and Andrés Velasco (2000). Exchange-Rate Policy for Developing Countries. American Economic Review, vol.90, n², pp. 71-75.

Collins, Susan M.(1996) On Becoming More Flexible: Exchange Rate Regimes in Latin America and the Caribbean. Journal of Development Economics, Vol. 51 pp. 117-138.

Dreyer, Jacob (1978) Determinants of Exchange Rate Regimes for Currencies of Developing Countries: Some Preliminary Results. World Development Vol.6 pp. 437 445.

Edwards, Sebastian (1996) The determinants of the choice between fixed and flexible exchange-rate regimes. NBER, WP 5756.

Frankel, Jeffrey and Andrew Rose (1998). The Endogeneity of the Optimum Currency Area Criteria. Economic Journal, Vol. 108, №449, pp.1009-1025.

Frankel, Jeffrey (1999). No Single Currency Regime Is Right For All Countries or At All Times, NBER,,WP 7338.

Frieden, Jeffry, Piero Ghezzi and Ernesto Stein (2000). Politics and Exchange Rates: A Cross-Country Approach to Latin America. Inter-American Development Bank, Research Network Working paper \#R-421.

Hausmann, Ricardo (1999) Should There Be Five Currencies or One Hundred and Five? Foreign Policy, Fall 1999.

Hausmann, Ricardo, Michael Gavin, Carmen Pages-Serra and Ernesto Stein (1999). Financial Turmoil and the Choice of Exchange Rate Regime. Inter-American Development Bank Working Paper \#400.

Hausmann, Ricardo, Ugo Panizza and Ernesto Stein (2000). Why do countries float the way they float? Inter-American Development Bank Working Paper \#418. 
Heller, Robert (1978). Determinants of Exchange Rate Practices. Journal of Money, Credit and Banking, Vol.10, No3, pp. 308-21.

Holden, Holden and Suss (1979). The Determinants of Exchange Rate Flexibility: An Empirical Investigation. The Review of Economics and Statistics, Vol. 61, Issue 3.

IMF, Economic Outlook (1997). Exchange Rate Arrangements and Economic Performance in Developing Countries, October 1997.

Kaminsky, Graciela and Sergio Schmukler. On the Booms ands Crashes: Financial Liberalization and Stock Market Cycles, available at www.worldbank.org/research/bios/schmukler.htm

Lane, P. July 1995. Determinants of Pegged Exchange Rates. Working paper.

Columbia University.

Levy-Yeyati, Eduardo and Federico Sturzenegger (2001a) Dollarization: A Primer, forthcoming in Dollarization, Levy-Yeyati, E. and F Sturzenegger, eds., MIT Press, Fall 2002, available at www.utdt.edu/ ely and www.utdt.edu/ $\sim$ fsturzen.

Levy-Yeyati, Eduardo and Federico Sturzenegger (2001b) Exchange Rate Regimes and Economic Perfomance, IMF Staff Papers. Vol. 47, pp. 62-98.

Levy-Yeyati, Eduardo and Federico Sturzenegger (2002) Deeds vs. Words: Classifying Exchange Rate Regimes, mimeo, Universidad Torcuato Di Tella, available at www.utdt.edu/ ely and www.utdt.edu/ fsturzen.

Melvin, M. (1985). The Choice of an Exchange Rate Regime and Macroeconomic Stability. Journal of Money, Credit, and Banking, 17, 467-78.

Mundell, Robert (1961). A Theory of Optimal Currency Areas. American Economic Review, Vol.51 No. 4, pp. 657-65.

Obstfeld, Maurice, and Alan Taylor, 2002, "Globalization and Capital Markets," NBER Working Paper No. 8846, March, forthcoming in the NBER conference volume edited by Michael Bordo, Alan Taylor, and Jeffrey Williamson.

Poirson, H.(2001). How do countries choose their exchange rate regime? IMF WP01/46.

Poole, William (1970) Optimal Choice of Monetary Policy Instruments in a Simple Stochastic Macro Model. Quarterly Journal of Economics, No. 84, pp. 197-216.

Rizzo, J (1998). The economic determinants of the choice of an exchange rate regime: a probit analysis. Economics Letters 59, pp.283-87.

Rose, Andrew (1999). One Money, One Market: Estimating the Effect of Common Currencies on Trade. NBER, WP 7432. 
Rose, Andrew and Jeffrey, Frankel (2002). An Estimate of the Effect of Currency Unions on Trade and Growth. Quarterly Journal of Economics, vol.117, Issue 2, pp. 437-466.

Rose, Andrew and Reuven Glick (2002). Does a currency union affect trade? The TimeSeries Evidence. The European Economic Review, vol. 46, Issue 6, pp.1125-1151.

Rose, Andrew and Eric Van Wincoop (2001). National money as a barrier to International Trade : The Real Case for Currency Union. American Economic Review, vol. $91 \mathrm{n}^{\circ} 2$, pp.386-390. 


\section{Table 1: Baseline Specification}

\begin{tabular}{|c|c|c|c|c|c|c|}
\hline & $\begin{array}{l}\text { (I) } \\
\text { Baseline }\end{array}$ & $\begin{array}{l}\text { (II) } \\
\text { Industrial }\end{array}$ & $\begin{array}{l}\text { (III) } \\
\text { Non-industrial }\end{array}$ & $\begin{array}{l}\text { (IV) } \\
\text { After 90's }\end{array}$ & $\begin{array}{l}(\mathrm{V}) \\
\text { Before 90's }\end{array}$ & $\begin{array}{l}(\mathrm{VI}) \\
\text { gdppc }< \\
\text { mean }\end{array}$ \\
\hline AREA & $\begin{array}{l}-0.316^{* * *} \\
(0.060)\end{array}$ & $\begin{array}{l}-0.714^{*} \\
(0.377)\end{array}$ & $\begin{array}{l}-0.243 \\
(0.193)\end{array}$ & $\begin{array}{l}-0.334 * * * \\
(0.069)\end{array}$ & $\begin{array}{l}-0.310 * * * \\
(0.089)\end{array}$ & $\begin{array}{l}-0.168 \\
(0.364)\end{array}$ \\
\hline SIZE & $\begin{array}{l}-5.252 * * \\
(2.158)\end{array}$ & $\begin{array}{l}-5.315 \\
(3.267)\end{array}$ & $\begin{array}{l}15.890 \\
(16.364)\end{array}$ & $\begin{array}{l}-9.817 * * * \\
(3.474)\end{array}$ & $\begin{array}{l}-1.890 \\
(2.565)\end{array}$ & $\begin{array}{l}-3.963 \\
(24.321)\end{array}$ \\
\hline OPEN1 & $\begin{array}{l}1.376^{*} \\
(0.764)\end{array}$ & $\begin{array}{l}28.154 * * * \\
(7.294)\end{array}$ & $\begin{array}{l}1.826^{* *} \\
(0.850)\end{array}$ & $\begin{array}{l}1.703 \\
(1.116)\end{array}$ & $\begin{array}{l}1.403 \\
(1.147)\end{array}$ & $\begin{array}{l}4.765 * * * \\
(1.402)\end{array}$ \\
\hline SHTRADE1 & $\begin{array}{l}1.739 * * * \\
(0.610)\end{array}$ & $\begin{array}{l}-18.640^{*} \\
(11.231)\end{array}$ & $\begin{array}{l}2.607 * * * \\
(0.668)\end{array}$ & $\begin{array}{l}1.469 * \\
(0.890)\end{array}$ & $\begin{array}{l}2.271 * * \\
(0.918)\end{array}$ & $\begin{array}{l}1.408 \\
(0.950)\end{array}$ \\
\hline LYSAVG2 & $\begin{array}{l}0.775^{*} \\
(0.409) \\
\end{array}$ & $\begin{array}{l}-26.544 * * \\
(11.293) \\
\end{array}$ & $\begin{array}{l}0.548 \\
(0.546) \\
\end{array}$ & $\begin{array}{l}0.818 \\
(0.641)\end{array}$ & $\begin{array}{l}0.370 \\
(0.592) \\
\end{array}$ & $\begin{array}{l}0.635 \\
(0.694) \\
\end{array}$ \\
\hline VOLEXT & $\begin{array}{l}-1.507 \\
(2.220)\end{array}$ & $\begin{array}{l}-33.009 \\
(28.327)\end{array}$ & $\begin{array}{l}-0.758 \\
(2.312)\end{array}$ & $\begin{array}{l}-3.123 \\
(3.390)\end{array}$ & $\begin{array}{l}2.272 \\
(4.075)\end{array}$ & $\begin{array}{l}-8.038 * * \\
(3.815)\end{array}$ \\
\hline VOLGOV5 & $\begin{array}{l}-0.459 \\
(0.439)\end{array}$ & $\begin{array}{l}-93.455^{* * *} \\
(26.615)\end{array}$ & $\begin{array}{l}-0.295 \\
(0.391)\end{array}$ & $\begin{array}{l}0.173 \\
(0.491)\end{array}$ & $\begin{array}{l}-1.161 \\
(0.862)\end{array}$ & $\begin{array}{l}-0.694 \\
(0.590)\end{array}$ \\
\hline VOLINV5 & $\begin{array}{l}3.134 \\
(4.225)\end{array}$ & $\begin{array}{l}-18.013 \\
(29.818)\end{array}$ & $\begin{array}{l}3.514 \\
(4.353)\end{array}$ & $\begin{array}{l}-1.049 \\
(5.631)\end{array}$ & $\begin{array}{l}4.183 \\
(5.970)\end{array}$ & $\begin{array}{l}-3.563 \\
(5.056)\end{array}$ \\
\hline VOLVELO5 & $\begin{array}{l}0.000 \\
(0.000) \\
\end{array}$ & $\begin{array}{l}1.500 * * * \\
(0.570) \\
\end{array}$ & $\begin{array}{l}0.000 \\
(0.000) \\
\end{array}$ & $\begin{array}{l}-0.030 * * \\
(0.015) \\
\end{array}$ & $\begin{array}{l}0.000 \\
(0.000) \\
\end{array}$ & $\begin{array}{l}0.000 \\
(0.000) \\
\end{array}$ \\
\hline MAJ & $\begin{array}{l}-1.307 * * * \\
(0.440)\end{array}$ & $\begin{array}{l}-5.901 * * \\
(2.486)\end{array}$ & $\begin{array}{l}-0.710 \\
(0.489)\end{array}$ & $\begin{array}{l}-0.895 \\
(0.660)\end{array}$ & $\begin{array}{l}-1.494 * * * \\
(0.570)\end{array}$ & $\begin{array}{l}-0.996 \\
(0.678)\end{array}$ \\
\hline YRSOFF & $\begin{array}{l}0.031 * * * \\
(0.011)\end{array}$ & $\begin{array}{l}-0.057 \\
(0.078)\end{array}$ & $\begin{array}{l}0.046^{* * * *} \\
(0.012)\end{array}$ & $\begin{array}{l}0.000 \\
(0.019)\end{array}$ & $\begin{array}{l}0.049 * * * \\
(0.015)\end{array}$ & $\begin{array}{l}0.020 \\
(0.014)\end{array}$ \\
\hline HERF & $\begin{array}{l}3.580 * * * \\
(1.362)\end{array}$ & $\begin{array}{l}-5.379 \\
(17.280)\end{array}$ & $\begin{array}{l}1.835 \\
(1.533)\end{array}$ & $\begin{array}{l}5.830 * * \\
(2.629)\end{array}$ & $\begin{array}{l}3.001 * \\
(1.686)\end{array}$ & $\begin{array}{l}1.308 \\
(1.820)\end{array}$ \\
\hline HERF2 & $\begin{array}{l}-1.392 \\
(1.096)\end{array}$ & $\begin{array}{l}39.700 \\
(27.749)\end{array}$ & $\begin{array}{l}-0.316 \\
(1.226)\end{array}$ & $\begin{array}{l}-3.340 \\
(2.126)\end{array}$ & $\begin{array}{l}-0.818 \\
(1.387)\end{array}$ & $\begin{array}{l}0.804 \\
(1.528)\end{array}$ \\
\hline DUMCI1 & $\begin{array}{l}-0.145 \\
(0.155) \\
\end{array}$ & $\begin{array}{l}1.292 * * \\
(0.637) \\
\end{array}$ & $\begin{array}{l}-0.176 \\
(0.182) \\
\end{array}$ & $\begin{array}{l}-0.840 * * * \\
(0.244) \\
\end{array}$ & $\begin{array}{l}0.434 * \\
(0.224) \\
\end{array}$ & $\begin{array}{l}-0.159 \\
(0.249) \\
\end{array}$ \\
\hline FINDEV & $\begin{array}{l}-0.478 * * \\
(0.202)\end{array}$ & & $\begin{array}{l}-1.198^{* * *} \\
(0.250)\end{array}$ & $\begin{array}{l}0.119 \\
(0.301)\end{array}$ & $\begin{array}{l}-0.955^{* * *} \\
(0.275)\end{array}$ & $\begin{array}{l}-1.126 * * * \\
(0.303)\end{array}$ \\
\hline QMM1 & $\begin{array}{l}-0.462 * * * \\
(0.070)\end{array}$ & $\begin{array}{l}-0.214 \\
(0.421)\end{array}$ & $\begin{array}{l}-0.377 * * * \\
(0.088)\end{array}$ & $\begin{array}{l}-0.571 * * * \\
(0.101)\end{array}$ & $\begin{array}{l}-0.339 * * * \\
(0.094)\end{array}$ & $\begin{array}{l}-0.369 * * \\
(0.161)\end{array}$ \\
\hline FLM1 & $\begin{array}{l}1.518 * * * \\
(0.181)\end{array}$ & $\begin{array}{l}-0.223 \\
(0.702)\end{array}$ & $\begin{array}{l}1.330 * * * \\
(0.391)\end{array}$ & $\begin{array}{l}1.679 * * * \\
(0.271)\end{array}$ & $\begin{array}{l}1.233 * * * \\
(0.258) \\
\end{array}$ & $\begin{array}{l}1.664 * * \\
(0.690) \\
\end{array}$ \\
\hline $\begin{array}{l}\text { Obs. } \\
\text { Pseudo R2 }\end{array}$ & $\begin{array}{l}1122 \\
0.258\end{array}$ & $\begin{array}{l}260 \\
0.656\end{array}$ & $\begin{array}{l}853 \\
0.265\end{array}$ & $\begin{array}{l}471 \\
0.253\end{array}$ & $\begin{array}{l}651 \\
0.297\end{array}$ & $\begin{array}{l}523 \\
0.257\end{array}$ \\
\hline Test OCA & $55.71 * * *$ & $42.39 * * *$ & $26.37 * * *$ & $45.75 * * *$ & $24.08 * * *$ & $25.38 * * *$ \\
\hline $\begin{array}{l}\text { Test nominal vs } \\
\text { real }\end{array}$ & 2.37 & $23.62 * * *$ & 1.48 & 5.53 & 3.26 & 7.42 \\
\hline Test policy crutch & $28.78 * * *$ & $24.91 * * *$ & $24.64 * * *$ & $17.45^{* * *}$ & $28.39 * * *$ & $20.63 * * *$ \\
\hline $\begin{array}{l}\text { Test impossible } \\
\text { trinity }\end{array}$ & $47.13 * * *$ & 0.26 & $35.75 * * *$ & $31.68 * * *$ & $21.31 * * *$ & $15.80 * * *$ \\
\hline $\begin{array}{l}\text { Test balance } \\
\text { sheet effects }\end{array}$ & $70.55 * * *$ & 0.10 & $11.54 * * *$ & $38.40 * * *$ & $22.83 * * *$ & $5.81 * *$ \\
\hline Time dummies & 29.54 & $50.99 * * *$ & $41.02 * * *$ & 6.00 & 17.20 & $31.12 *$ \\
\hline
\end{tabular}


Table 2: De Jure and De Facto Classification

\begin{tabular}{|c|c|c|c|}
\hline & \begin{tabular}{|l} 
(I) \\
Baseline
\end{tabular} & $\begin{array}{l}\text { (II) } \\
\text { De Jure Classification }\end{array}$ & $\begin{array}{l}\text { (III) } \\
\text { Uncontroversials }\end{array}$ \\
\hline AREA & $\begin{array}{l}-0.316^{* * * *} \\
(0.060)\end{array}$ & $\begin{array}{l}-0.024 \\
(0.086)\end{array}$ & $\begin{array}{l}-0.117 \\
(0.127)\end{array}$ \\
\hline SIZE & $\begin{array}{l}-5.252 * * \\
(2.158)\end{array}$ & $\begin{array}{l}-32.613 * * * \\
(7.708)\end{array}$ & $\begin{array}{l}-42.360 * * * \\
(14.178)\end{array}$ \\
\hline OPEN1 & $\begin{array}{l}1.376^{*} \\
(0.764)\end{array}$ & $\begin{array}{l}1.611^{* *} \\
(0.819)\end{array}$ & $\begin{array}{l}0.930 \\
(0.865)\end{array}$ \\
\hline SHTRADE1 & $\begin{array}{l}1.739 * * * \\
(0.610)\end{array}$ & $\begin{array}{l}1.430 * * \\
(0.574)\end{array}$ & $\begin{array}{l}2.482 * * * \\
(0.732)\end{array}$ \\
\hline LYSAVG2 & $\begin{array}{l}0.775^{*} \\
(0.409) \\
\end{array}$ & $\begin{array}{l}2.614 * * * \\
(0.464) \\
\end{array}$ & $\begin{array}{l}2.583 * * * \\
(0.534) \\
\end{array}$ \\
\hline VOLEXT & \begin{tabular}{|l|}
-1.507 \\
$(2.220)$
\end{tabular} & $\begin{array}{l}0.265 \\
(2.488)\end{array}$ & $\begin{array}{l}-2.066 \\
(2.670)\end{array}$ \\
\hline VOLGOV5 & $\begin{array}{l}-0.459 \\
(0.439)\end{array}$ & $\begin{array}{l}0.193 \\
(0.377)\end{array}$ & $\begin{array}{l}-1.686 \\
(1.152)\end{array}$ \\
\hline VOLINV5 & $\begin{array}{l}3.134 \\
(4.225)\end{array}$ & $\begin{array}{l}5.446 \\
(4.304)\end{array}$ & $\begin{array}{l}1.964 \\
(4.519)\end{array}$ \\
\hline VOLVELO5 & \begin{tabular}{|l|}
0.000 \\
$(0.000)$ \\
\end{tabular} & $\begin{array}{l}-0.000 * * \\
(0.000)\end{array}$ & $\begin{array}{l}-0.000 \\
(0.000)\end{array}$ \\
\hline MAJ & $\begin{array}{l}-1.307 * * * \\
(0.440)\end{array}$ & $\begin{array}{l}0.556 \\
(0.466)\end{array}$ & $\begin{array}{l}-0.593 \\
(0.532)\end{array}$ \\
\hline YRSOFF & $\begin{array}{l}0.031 * * * \\
(0.011)\end{array}$ & $\begin{array}{l}0.025 * * \\
(0.011)\end{array}$ & $\begin{array}{l}0.035 * * * \\
(0.012)\end{array}$ \\
\hline HERF & $\begin{array}{l}3.580 * * * \\
(1.362)\end{array}$ & $\begin{array}{l}-1.968 \\
(1.295)\end{array}$ & $\begin{array}{l}1.757 \\
(1.542)\end{array}$ \\
\hline HERF2 & $\begin{array}{l}-1.392 \\
(1.096)\end{array}$ & $\begin{array}{l}1.592 \\
(1.064)\end{array}$ & $\begin{array}{l}-1.033 \\
(1.231)\end{array}$ \\
\hline DUMCI1 & $\begin{array}{l}-0.145 \\
(0.155) \\
\end{array}$ & $\begin{array}{l}-0.000 \\
(0.165)\end{array}$ & $\begin{array}{l}0.268 \\
(0.187) \\
\end{array}$ \\
\hline FINDEV & $\begin{array}{l}-0.478 * * \\
(0.202)\end{array}$ & $\begin{array}{l}-0.680 * * * \\
(0.215)\end{array}$ & $\begin{array}{l}-1.406 * * * \\
(0.274)\end{array}$ \\
\hline QMM1 & $\begin{array}{l}-0.462 * * * \\
(0.070)\end{array}$ & $\begin{array}{l}0.022 \\
(0.042) \\
\end{array}$ & $\begin{array}{l}-0.340 * * * \\
(0.086)\end{array}$ \\
\hline FLM1 & $\begin{array}{l}1.518 * * * \\
(0.181) \\
\end{array}$ & $\begin{array}{l}0.159 \\
(0.103)\end{array}$ & $\begin{array}{l}1.559 * * * \\
(0.297)\end{array}$ \\
\hline $\begin{array}{l}\text { Obs. } \\
\text { Pseudo R2 }\end{array}$ & \begin{tabular}{l|}
1122 \\
0.258 \\
\end{tabular} & $\begin{array}{l}1122 \\
0.346\end{array}$ & $\begin{array}{l}1122 \\
0.394\end{array}$ \\
\hline Correctly classified & $72.55 \%$ & $77.99 \%$ & $80.66 \%$ \\
\hline Test OCA & $\overline{555.71 * * *}$ & $70.69 * * *$ & $67.06^{* * *}$ \\
\hline Test nominal vs real & 2.37 & 6.70 & 5.74 \\
\hline Test policy crutch & $28.78 * * *$ & $11.30 * *$ & $12.71 * *$ \\
\hline Test impossible trinity & $47.13 * * *$ & $10.01 * *$ & $41.52 * * *$ \\
\hline Test balance sheet effects & $70.55^{* * *}$ & 2.42 & $27.53 * * *$ \\
\hline Time dummies & 29.54 & $58.17 * * *$ & $43.65 * * *$ \\
\hline
\end{tabular}




\section{Table 3: Extension: Sustainability}

\begin{tabular}{|c|c|c|c|c|}
\hline & $\begin{array}{l}\text { (I) } \\
\text { Baseline }\end{array}$ & $\begin{array}{l}\text { (II) } \\
\text { w/Reserves }\end{array}$ & $\begin{array}{l}\text { (III) } \\
\text { w/Inflation }\end{array}$ & $\begin{array}{l}\text { (IV) } \\
\text { w/Reserves + Inflation }\end{array}$ \\
\hline AREA & $\begin{array}{l}-0.316^{* * *} \\
(0.060)\end{array}$ & $\begin{array}{l}-0.282 * * * \\
(0.058)\end{array}$ & $\begin{array}{l}-0.318^{* * * *} \\
(0.067)\end{array}$ & $\begin{array}{l}-0.253 * * * \\
(0.070)\end{array}$ \\
\hline SIZE & $\begin{array}{l}-5.252 * * \\
(2.158)\end{array}$ & $\begin{array}{l}-5.673 * * \\
(2.593)\end{array}$ & $\begin{array}{l}-6.444 * * * \\
(2.292)\end{array}$ & $\begin{array}{l}-7.093 * * \\
(2.791)\end{array}$ \\
\hline OPEN1 & $\begin{array}{l}1.376^{*} \\
(0.764)\end{array}$ & $\begin{array}{l}1.530^{*} \\
(0.792)\end{array}$ & $\begin{array}{l}0.583 \\
(0.791)\end{array}$ & $\begin{array}{l}0.778 \\
(0.826)\end{array}$ \\
\hline SHTRADE1 & $\begin{array}{l}1.739 * * * \\
(0.610)\end{array}$ & $\begin{array}{l}1.799 * * * \\
(0.614)\end{array}$ & $\begin{array}{l}1.948 * * * \\
(0.664)\end{array}$ & $\begin{array}{l}2.061 * * * \\
(0.670)\end{array}$ \\
\hline LYSAVG2 & $\begin{array}{l}0.775 * \\
(0.409)\end{array}$ & $\begin{array}{l}0.906 * * \\
(0.429)\end{array}$ & $\begin{array}{l}0.762 * \\
(0.400)\end{array}$ & $\begin{array}{l}0.904 * * \\
(0.427)\end{array}$ \\
\hline VOLEXT & $\begin{array}{l}-1.507 \\
(2.220)\end{array}$ & $\begin{array}{l}-2.538 \\
(2.326)\end{array}$ & $\begin{array}{l}-0.287 \\
(2.184)\end{array}$ & $\begin{array}{l}-1.350 \\
(2.375)\end{array}$ \\
\hline VOLGOV5 & $\begin{array}{l}-0.459 \\
(0.439)\end{array}$ & $\begin{array}{l}-0.589 \\
(0.510)\end{array}$ & $\begin{array}{l}0.715 \\
(0.556)\end{array}$ & $\begin{array}{l}0.646 \\
(0.536)\end{array}$ \\
\hline VOLINV5 & $\begin{array}{l}3.134 \\
(4.225)\end{array}$ & $\begin{array}{l}1.433 \\
(4.451)\end{array}$ & $\begin{array}{l}6.566 \\
(4.057)\end{array}$ & $\begin{array}{l}4.507 \\
(4.275)\end{array}$ \\
\hline VOLVELO5 & $\begin{array}{l}0.000 \\
(0.000) \\
\end{array}$ & $\begin{array}{l}0.000 \\
(0.000) \\
\end{array}$ & $\begin{array}{l}0.000 \\
(0.000) \\
\end{array}$ & $\begin{array}{l}0.000 \\
(0.000) \\
\end{array}$ \\
\hline MAJ & $\begin{array}{l}-1.307 * * * \\
(0.440)\end{array}$ & $\begin{array}{l}-1.123 * * * \\
(0.434)\end{array}$ & $\begin{array}{l}-1.530 * * * \\
(0.433)\end{array}$ & $\begin{array}{l}-1.345 * * * \\
(0.431)\end{array}$ \\
\hline YRSOFF & $\begin{array}{l}0.031 * * * \\
(0.011)\end{array}$ & $\begin{array}{l}0.042 * * * \\
(0.012)\end{array}$ & $\begin{array}{l}0.022 * * \\
(0.010)\end{array}$ & $\begin{array}{l}0.033 * * * \\
(0.011)\end{array}$ \\
\hline HERF & $\begin{array}{l}3.580 * * * \\
(1.362)\end{array}$ & $\begin{array}{l}2.699 * * \\
(1.343)\end{array}$ & $\begin{array}{l}4.387 * * * \\
(1.332)\end{array}$ & $\begin{array}{l}3.496 * * * \\
(1.325)\end{array}$ \\
\hline HERF2 & $\begin{array}{l}-1.392 \\
(1.096)\end{array}$ & $\begin{array}{l}-0.752 \\
(1.117)\end{array}$ & $\begin{array}{l}-1.947^{*} \\
(1.085)\end{array}$ & $\begin{array}{l}-1.324 \\
(1.117)\end{array}$ \\
\hline DUMCI1 & $\begin{array}{l}-0.145 \\
(0.155)\end{array}$ & $\begin{array}{l}-0.164 \\
(0.160)\end{array}$ & $\begin{array}{l}-0.168 \\
(0.157)\end{array}$ & $\begin{array}{l}-0.191 \\
(0.164)\end{array}$ \\
\hline INF1 & & & $\begin{array}{l}-3.477 * * * \\
(0.941)\end{array}$ & $\begin{array}{l}-3.353 * * * \\
(0.850)\end{array}$ \\
\hline HIGH & & & $\begin{array}{l}2.569 * * * \\
(0.983)\end{array}$ & $\begin{array}{l}2.411 * * * \\
(0.884)\end{array}$ \\
\hline RESBASE1 & & $\begin{array}{l}0.818 * * * \\
(0.107) \\
\end{array}$ & & $\begin{array}{l}0.852 * * * \\
(0.125)\end{array}$ \\
\hline QMM1 & $\begin{array}{l}-0.462 * * * \\
(0.070)\end{array}$ & $\begin{array}{l}-0.590 * * * \\
(0.084)\end{array}$ & $\begin{array}{l}-0.437 * * * \\
(0.073)\end{array}$ & $\begin{array}{l}-0.577 * * * \\
(0.090)\end{array}$ \\
\hline FINDEV & $\begin{array}{l}-0.478^{* *} \\
(0.202)\end{array}$ & $\begin{array}{l}-0.941 * * * \\
(0.218)\end{array}$ & $\begin{array}{l}-0.402 * * \\
(0.203)\end{array}$ & $\begin{array}{l}-0.872 * * * \\
(0.220)\end{array}$ \\
\hline FLM1 & $\begin{array}{l}1.518 * * * \\
(0.181)\end{array}$ & $\begin{array}{l}1.539 * * * \\
(0.186)\end{array}$ & $\begin{array}{l}1.409 * * * \\
(0.189)\end{array}$ & $\begin{array}{l}1.457^{* * * *} \\
(0.197)\end{array}$ \\
\hline $\begin{array}{l}\text { Obs. } \\
\text { Pseudo R2 }\end{array}$ & $\begin{array}{l}1122 \\
0.258\end{array}$ & $\begin{array}{l}1109 \\
0.286\end{array}$ & $\begin{array}{l}1096 \\
0.277\end{array}$ & $\begin{array}{l}1083 \\
0.305\end{array}$ \\
\hline Test OCA & $55.71 * * *$ & $57.20^{* * *}$ & $49.18 * * *$ & $42.77 * * *$ \\
\hline Test nominal vs real & 2.37 & 3.26 & 5.91 & 3.63 \\
\hline Test policy crutch & $28.78 * * *$ & $86.05 * * *$ & $50.88 * * *$ & $112.94 * * *$ \\
\hline Test impossible trinity & $47.13 * * *$ & $59.07 * * *$ & $38.78 * * *$ & $49.10 * * *$ \\
\hline Test balance sheet effects & $70.55 * * *$ & $68.40 * * *$ & $55.82 * * *$ & $54.66 * * *$ \\
\hline Time dummies & 29.54 & 30.53 & $32.92 *$ & $34.89 * *$ \\
\hline
\end{tabular}

Robust standard errors in parentheses

Statistics are chi-squared distributed

* significant at $10 \%$; $*$ significant at $5 \%$; ** significant at $1 \%$ 


\section{Table 4: Endogeneity}

\begin{tabular}{|c|c|c|c|}
\hline & $\begin{array}{l}\text { (I) } \\
\text { w/lagged inflation }\end{array}$ & $\begin{array}{l}\text { (II) } \\
\text { w/lagged trade }\end{array}$ & $\begin{array}{l}\text { (III) } \\
\text { Fixed effects }\end{array}$ \\
\hline AREA & $\begin{array}{l}-0.312 * * * \\
(0.062)\end{array}$ & $\begin{array}{l}-0.364 * * * \\
(0.067)\end{array}$ & \\
\hline SIZE & $\begin{array}{l}-6.314 * * * \\
(2.253)\end{array}$ & $\begin{array}{l}-3.232 \\
(2.127)\end{array}$ & $\begin{array}{l}-11.126 \\
(13.713)\end{array}$ \\
\hline OPEN1 & $\begin{array}{l}0.530 \\
(0.918)\end{array}$ & & $\begin{array}{l}4.545^{* *} \\
(2.087)\end{array}$ \\
\hline OPEN1I & & $\begin{array}{l}1.914 * * * \\
(0.699)\end{array}$ & \\
\hline SHTRADE1 & $\begin{array}{l}1.669 * * * \\
(0.644)\end{array}$ & & $\begin{array}{l}1.750 \\
(1.316)\end{array}$ \\
\hline SHTRADEI & & $\begin{array}{l}3.350 * * * \\
(0.739)\end{array}$ & \\
\hline LYSAVG2 & $\begin{array}{l}0.704 * \\
(0.393)\end{array}$ & $\begin{array}{l}0.612 \\
(0.421)\end{array}$ & $\begin{array}{l}3.564 * * * \\
(0.764) \\
\end{array}$ \\
\hline VOLEXT & $\begin{array}{l}-2.009 \\
(2.635)\end{array}$ & $\begin{array}{l}-1.659 \\
(1.833)\end{array}$ & $\begin{array}{l}-4.050 \\
(3.419)\end{array}$ \\
\hline VOLGOV5 & $\begin{array}{l}1.444 \\
(0.955)\end{array}$ & $\begin{array}{l}-0.442 \\
(0.480)\end{array}$ & $\begin{array}{l}-0.245 \\
(0.606)\end{array}$ \\
\hline VOLINV5 & $\begin{array}{l}3.901 \\
(3.875)\end{array}$ & $\begin{array}{l}11.095 * * \\
(4.613)\end{array}$ & $\begin{array}{l}14.438 * * \\
(7.216)\end{array}$ \\
\hline VOLVELO5 & $\begin{array}{l}0.000 \\
(0.000) \\
\end{array}$ & $\begin{array}{l}-0.000 \\
(0.000)\end{array}$ & $\begin{array}{l}0.000 * * * \\
(0.000)\end{array}$ \\
\hline MAJ & $\begin{array}{l}-1.541 * * * \\
(0.439)\end{array}$ & $\begin{array}{l}-1.563 * * * \\
(0.459)\end{array}$ & $\begin{array}{l}-1.913 * * \\
(0.769)\end{array}$ \\
\hline YRSOFF & $\begin{array}{l}0.026^{* * *} \\
(0.011)\end{array}$ & $\begin{array}{l}0.032 * * * \\
(0.011)\end{array}$ & $\begin{array}{l}0.040^{*} \\
(0.024)\end{array}$ \\
\hline HERF & $\begin{array}{l}4.359 * * * \\
(1.362)\end{array}$ & $\begin{array}{l}3.607 * * \\
(1.409)\end{array}$ & $\begin{array}{l}-2.465 \\
(2.614)\end{array}$ \\
\hline HERF2 & $\begin{array}{l}-1.898^{*} \\
(1.122)\end{array}$ & $\begin{array}{l}-1.241 \\
(1.116)\end{array}$ & $\begin{array}{l}3.970^{*} \\
(2.187)\end{array}$ \\
\hline DUMCI1 & $\begin{array}{l}-0.187 \\
(0.160)\end{array}$ & $\begin{array}{l}-0.249 \\
(0.161)\end{array}$ & $\begin{array}{l}-0.390 \\
(0.239)\end{array}$ \\
\hline $\begin{array}{l}\text { INF3 } \\
\text { HIGH }\end{array}$ & $\begin{array}{l}-3.195^{*} \\
(1.873) \\
1.947 \\
(1.378) \\
\end{array}$ & & \\
\hline FINDEV & $\begin{array}{l}-0.296 \\
(0.204)\end{array}$ & $\begin{array}{l}-0.254 \\
(0.205)\end{array}$ & \\
\hline QMM1 & $\begin{array}{l}-0.394 * * * \\
(0.076)\end{array}$ & $\begin{array}{l}-0.417 * * * \\
(0.070)\end{array}$ & $\begin{array}{l}-0.559 * * * \\
(0.191)\end{array}$ \\
\hline FLM1 & $\begin{array}{l}1.311^{* * * *} \\
(0.188)\end{array}$ & $\begin{array}{l}1.498^{* * * *} \\
(0.184)\end{array}$ & $\begin{array}{l}1.697 * * * \\
(0.513)\end{array}$ \\
\hline $\begin{array}{l}\text { Obs. } \\
\text { Number of code } \\
\text { Pseudo R2 }\end{array}$ & $\begin{array}{l}1038 \\
0.255\end{array}$ & $\begin{array}{l}1076 \\
0.278\end{array}$ & $\begin{array}{l}794 \\
53 \\
0.248 \\
\end{array}$ \\
\hline Test OCA & $42.30^{* * *}$ & $69.81 * * *$ & $27.39^{* * *}$ \\
\hline Test nominal vs real & 5.69 & 6.10 & $8.88^{*}$ \\
\hline Test policy crutch & $33.39 * * *$ & $31.42 * * *$ & $14.88^{* *}$ \\
\hline Test impossible trinity & $28.69^{* * *}$ & $35.55 * * *$ & $8.56^{* * *}$ \\
\hline Test balance sheet effects & $48.95^{* * *}$ & $66.56^{* * *}$ & $10.92 * * *$ \\
\hline Time dummies & 29.77 & $31.38^{*}$ & $44.17 * * *$ \\
\hline
\end{tabular}


Table 5: Fear of floating and Fear of pegging

\begin{tabular}{|c|c|c|}
\hline & $\begin{array}{l}\text { (I) } \\
\text { Fear of floating }\end{array}$ & $\begin{array}{l}\text { (II) } \\
\text { Fear of pegging }\end{array}$ \\
\hline AREA & $\begin{array}{l}-0.205^{* *} \\
(0.096)\end{array}$ & $\begin{array}{l}1.142 * * * \\
(0.365)\end{array}$ \\
\hline SIZE & $\begin{array}{l}-9.818^{*} \\
(5.244)\end{array}$ & $\begin{array}{l}33.858^{* * *} \\
(12.104)\end{array}$ \\
\hline OPEN1 & $\begin{array}{l}3.805 \\
(2.421)\end{array}$ & $\begin{array}{l}0.887 \\
(1.809)\end{array}$ \\
\hline SHTRADE1 & $\begin{array}{l}-0.280 \\
(1.538)\end{array}$ & $\begin{array}{l}-3.362 * * * \\
(1.165)\end{array}$ \\
\hline LYSAVG2 & $\begin{array}{l}-1.980 \\
(1.351)\end{array}$ & $\begin{array}{l}-4.451 * * * \\
(0.988)\end{array}$ \\
\hline VOLEXT & $\begin{array}{l}4.760 \\
(6.096)\end{array}$ & $\begin{array}{l}6.011 \\
(3.971)\end{array}$ \\
\hline VOLGOV5 & $\begin{array}{l}6.914 * * \\
(2.904)\end{array}$ & $\begin{array}{l}0.817 \\
(1.206)\end{array}$ \\
\hline VOLINV5 & $\begin{array}{l}-3.948 \\
(8.119)\end{array}$ & $\begin{array}{l}-13.500 \\
(8.768)\end{array}$ \\
\hline VOLVELO5 & $\begin{array}{l}0.474 * * \\
(0.222)\end{array}$ & $\begin{array}{l}0.000 \\
(0.000)\end{array}$ \\
\hline MAJ & $\begin{array}{l}-1.426 \\
(1.316)\end{array}$ & $\begin{array}{l}-2.677^{*} \\
(1.485)\end{array}$ \\
\hline YRSOFF & $\begin{array}{l}0.078 \\
(0.064)\end{array}$ & $\begin{array}{l}-0.050 * * \\
(0.022)\end{array}$ \\
\hline HERF & $\begin{array}{l}-7.042 \\
(4.925)\end{array}$ & $\begin{array}{l}3.213 \\
(2.469)\end{array}$ \\
\hline HERF2 & $\begin{array}{l}6.000 \\
(4.558)\end{array}$ & $\begin{array}{l}-0.746 \\
(2.088)\end{array}$ \\
\hline DUMCI1 & $\begin{array}{l}-0.289 \\
(0.478)\end{array}$ & $\begin{array}{l}-0.155 \\
(0.307)\end{array}$ \\
\hline FINDEV & $\begin{array}{l}0.133 \\
(0.672)\end{array}$ & $\begin{array}{l}1.574 * * * \\
(0.451)\end{array}$ \\
\hline QMM1 & $\begin{array}{l}0.110 \\
(0.238) \\
\end{array}$ & $\begin{array}{l}-0.120 \\
(0.129) \\
\end{array}$ \\
\hline FLM1 & $\begin{array}{l}1.244^{* *} \\
(0.563)\end{array}$ & $\begin{array}{l}-0.158 \\
(0.096)\end{array}$ \\
\hline $\begin{array}{l}\text { Obs. } \\
\text { Pseudo R2 }\end{array}$ & $\begin{array}{l}221 \\
0.443 \\
\end{array}$ & $\begin{array}{l}510 \\
0.481 \\
\end{array}$ \\
\hline Test OCA & $19.20 * * *$ & $51.90 * * *$ \\
\hline Test nominal vs real & $13.11 * *$ & 5.69 \\
\hline Test policy crutch & 4.29 & 8.96 \\
\hline Test impossible trinity & 0.27 & $12.21 * * *$ \\
\hline Test balance sheet effects & $4.88 * *$ & 2.68 \\
\hline Time dummies & 27.61 & $43.49 * * *$ \\
\hline
\end{tabular}


Figure 1. Time Trends

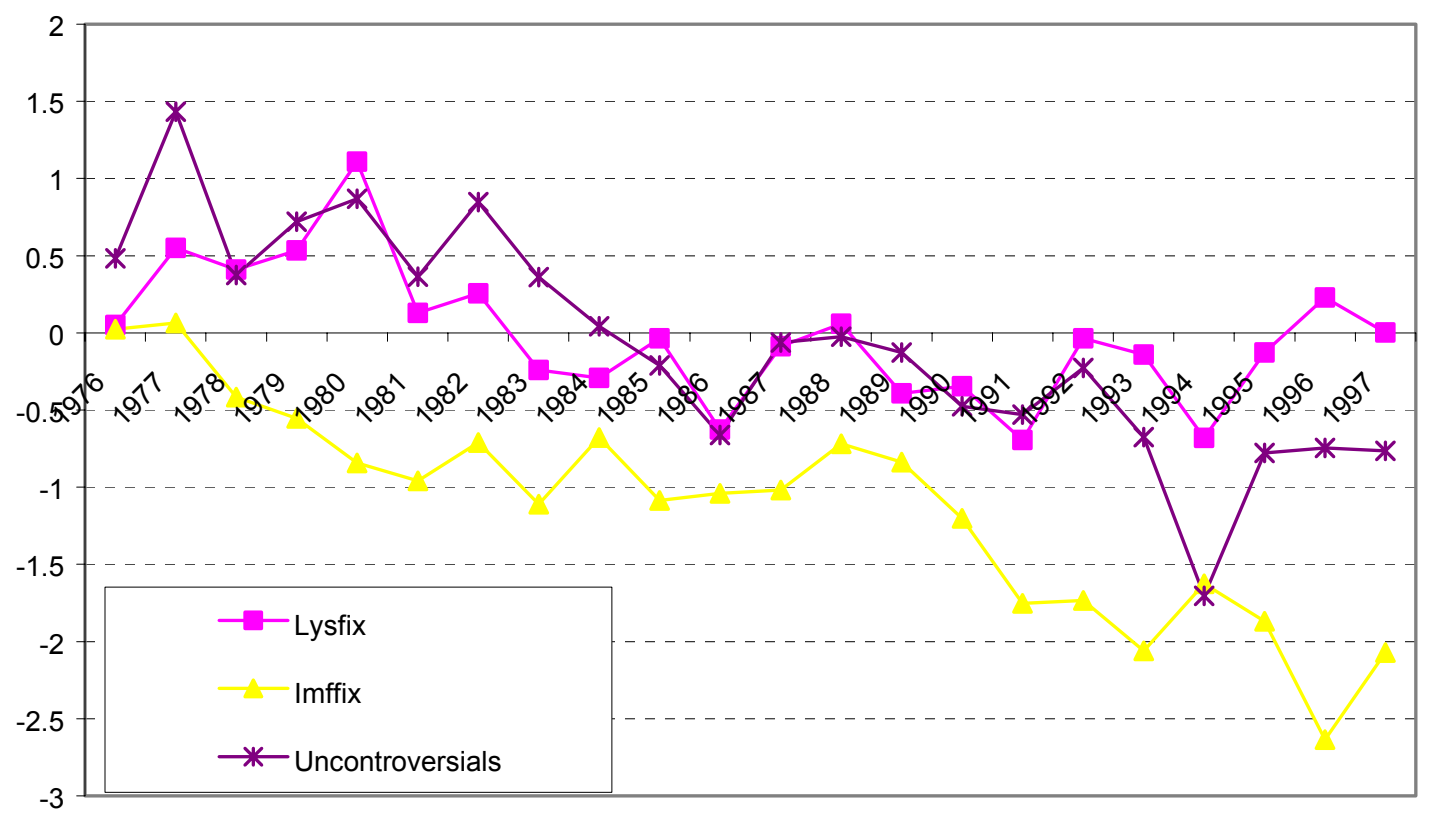


APPENDIX

\begin{tabular}{|c|c|}
\hline Variables & Definition and Source \\
\hline AREA & Land area (sq km) (Source: WDI,; variable AG.LND.TOTL.K2) \\
\hline DUMCI1 & $\begin{array}{l}\text { Dummy variable for economic cycle ( } 1 \text { if the GDP growth rate in the } \\
\text { preceding period is above the long-run growth rate). (Source:WEO-IMF } \\
\text { Series code:W914NGDP_R) }\end{array}$ \\
\hline FINDEV & Dummy variable for emerging and industrial countries. \\
\hline FLM1 & $\begin{array}{l}\text { Lagged Ratio of Foreign Liabilities to Money (Source: IMF line 16C/ } \\
\text { line 34). }\end{array}$ \\
\hline HERF & $\begin{array}{l}\text { The sum of the squared seat shares of all parties in the government } \\
\text { (Source: Database of Political Institutions. Version 2.0) }\end{array}$ \\
\hline HERF2 & Square of HERF. \\
\hline HIGH & $\begin{array}{l}\text { Variable for High Inflation (annual rate greater than } 150 \% \text { in the previous } \\
\text { year). }\end{array}$ \\
\hline INF1 & $\begin{array}{l}\text { Lagged logarithm of one plus the annual percentage change in Consumer } \\
\text { Price Index (Source: IMF line 64). }\end{array}$ \\
\hline INF3 & Average inflation of the previous three years.(Source: IMF line 64) \\
\hline LYSAVG & $\begin{array}{l}\text { Average de facto exchange rate regime of the region (Source: Levy } \\
\text { Yeyati and Sturzenegger (2002) }\end{array}$ \\
\hline MAJ & $\begin{array}{l}\text { Fraction of seats held by the government. It is calculated by dividing the } \\
\text { number of government seats by total (government plus opposition) seats. } \\
\text { (Source: Database of Political Institutions. Version 2.0) }\end{array}$ \\
\hline OPEN1 & $\begin{array}{l}\text { Lagged Openness, (ratio of [export + import] } / 2 \text { to GDP) (Source: IMF } \\
\text { (line } 90 \mathrm{c}+\text { line } 98 \mathrm{c} \text { ) } / 2 / \text { line } 99 \mathrm{~b} \text { ). }\end{array}$ \\
\hline QMM1 & Lagged Ratio of Quasi Money over Money (Source: IMF line 35/ line 34) \\
\hline RESBASE1 & $\begin{array}{l}\text { Lagged Ratio of International Reserves to monetary base (Source: IMF } \\
\text { line 11/line 14). }\end{array}$ \\
\hline RESBASEI & 1974 Ratio of International Reserves to monetary base (Source: IMF ). \\
\hline SHTRADE1 & $\begin{array}{l}\text { Lagged share of trade with the largest trading partner: exports to the } \\
\text { largest trading partner as a share of total exports (Source: IMF-Direction } \\
\text { of Trade Statistics). }\end{array}$ \\
\hline SHTRADEI & $\begin{array}{l}1974 \text { share of trade with the largest trading partner: exports to the largest } \\
\text { trading partner as a share of total exports (Source: IMF-Direction of } \\
\text { Trade Statistics). }\end{array}$ \\
\hline SIZE & $\begin{array}{l}\text { GDP in dollars over USA GDP (Source: WDI Series Code: } \\
\text { NY.GDP.MKTP.CD). }\end{array}$ \\
\hline VOLEXT & $\begin{array}{l}\text { Standard deviation of the logarithm of terms of trade over the previous } \\
\text { five years adjusted by openness (Source: WDI Series Code: } \\
\text { NY.EXP.CAPM.KN) }\end{array}$ \\
\hline VOLGOV5 & $\begin{array}{l}\text { Standard deviation of the government consumption to GDP ratio over the } \\
\text { previous five years. (Source: IMF line } 82 / \text { line } 99 \mathrm{~b} \text { ) }\end{array}$ \\
\hline VOLINV5 & $\begin{array}{l}\text { Standard deviation of the investment to GDP ratio over the previous five } \\
\text { years. (Source: IMF line } 93 \mathrm{e} / \text { line } 99 \mathrm{~b} \text { ) }\end{array}$ \\
\hline VOLVELO5 & $\begin{array}{l}\text { Standard deviation of money velocity over the previous five years. } \\
\text { (Source: IMF line 99b/ line 34)) }\end{array}$ \\
\hline YRSOFF & Years the incumbent administration has been in office. \\
\hline
\end{tabular}




\section{Universidad Torcuato Di Tella, Business School Working Papers}

\section{Working Papers 2003}

NN16 "Business Cycle and Macroeconomic Policy Coordination in MERCOSUR"

Martín Gonzalez Rozada (UTDT) y José Fanelli (CEDES).

No15 "The Fiscal Spending Gap and the Procyclicality of Public Expenditure"

Eduardo Levy Yeyati (UTDT) y Sebastián Galiani (UDESA).

No14 "Financial Dollarization and Debt Deflation under a Currency Board"

Eduardo Levy Yeyati (UTDT), Ernesto Schargrodsky (UTDT) y Sebastián Galiani (UDESA).

№13 " ¿ Por qué crecen menos los regímenes de tipo de cambio fijo? El efecto de los Sudden Stops", Federico Stuzenegger (UTDT).

№12 "Concentration and Foreign Penetration in Latin American Banking Sectors: Impact on Competition and Risk", Eduardo Levy Yeyati (UTDT) y Alejandro Micco (IADB).

№11 "Default 's in the 1990's: What have we learned?",

Federico Sturzenegger (UTDT) y Punan Chuham (WB).

№10 "Un año de medición del Indice de Demanda Laboral: situación actual y perspectivas",

Victoria Lamdany (UTDT) y Luciana Monteverde (UTDT)

N'09 "Liquidity Protection versus Moral Hazard: The Role of the IMF",

Andrew Powell (UTDT) y Leandro Arozamena (UTDT)

№8 "Financial Dedollarization: A Carrot and Stick Approach", Eduardo Levy Yeyati (UTDT)

No07 "The Price of Inconvertible Deposits: The Stock Market Boom during the Argentine crisis",

Eduardo Levy Yeyati (UTDT), Sergio Schmukler (WB) y Neeltje van Horen (WB)

NN06 "Aftermaths of Current Account Crisis: Export Growth or Import Contraction?",

Federico Sturzenegger (UTDT), Pablo Guidotti (UTDT) y Agustín Villar (BIS)

No5 "Regional Integration and the Location of FDI",

Eduardo Levy Yeyati (UTDT), Christian Daude (UM ) y Ernesto Stein (BID)

N04 "A new test for the success of inflation targeting",

Andrew Powell (UTDT), Martin Gonzalez Rozada (UTDT) y Verónica Cohen Sabbán (BCRA)

No03 "Living and Dying with Hard Pegs: The Rise and Fall of Argentina's Currency Board",

Eduardo Levy Yeyati (UTDT), Augusto de la Torre (WB) y Sergio Schmukler (WB)

No02 "The Cyclical Nature of FDI flows",

Eduardo Levy Yeyati (UTDT), Ugo Panizza (BID) y Ernesto Stein (BID) 
№1 "Endogenous Deposit Dollarization",

Eduardo Levy Yeyati (UTDT) y Christian Broda (FRBNY)

\section{Working Papers 2002}

№15 "The FTAA and the Location of FDI",

Eduardo Levy Yeyati (UTDT), Christian Daude (UM ) y Ernesto Stein ( BID)

No14 "Macroeconomic Coordination and Monetary Unions in a N-country World: Do all Roads

Lead to Rome?"

Federico Sturzenegger (UTDT) y Andrew Powell (UTDT)

№13 "Reforming Capital Requirements in Emerging Countries"

Andrew Powell (UTDT), Verónica Balzarotti (BCRA) y Christian Castro (UPF)

№12 "Toolkit for the Analysis of Debt Problems", Federico Sturzenegger (UTDT)

№11 "On the Endogeneity of Exchange Rate Regimes",

Eduardo Levy Yeyati (UTDT), Federico Sturzenegger (UTDT) e lliana Reggio (UCLA)

№10 "Defaults in the 90's: Factbook and Preliminary Lessons", Federico Sturzenegger (UTDT)

No09 "Countries with international payments ' difficulties: what can the IMF do?"

Andrew Powell (UTDT)

NN08 "The Argentina Crisis: Bad Luck, Bad Management, Bad Politics, Bad Advice",

Andrew Powell (UTDT)

N07 "Capital Inflows and Capital Outflows: Measurement, Determinants, Consequences",

Andrew Powell (UTDT), Dilip Ratha (WB) y Sanket Mohapatra (CU)

No06 "Banking on Foreigners: The Behaviour of International Bank Lending to Latin America, 1985-2000",

Andrew Powell (UTDT), María Soledad Martinez Peria (WB) y Ivanna Vladkova ( IMF)

No05 "Classifying Exchange Rate Regimes: Deeds vs. Words"

Eduardo Levy Yeyati (UTDT) y Federico Sturzenegger (UTDT)

NN04 "The Effect of Product Market Competition on Capital Structure: Empirical Evidence from the

Newspaper Industry", Ernesto Schargrodsky (UTDT)

N03 "Financial globalization: Unequal blessings",

Augusto de la Torre (World Bank), Eduardo Levy Yeyati (Universidad Torcuato Di Tella) y Sergio

L. Schmukler (World Bank)

N02 "Inference and estimation in small sample dynamic panel data models",

Sebastian Galiani (UdeSA) y Martin Gonzalez-Rozada (UTDT)

№1 "Why have poverty and income inequality increased so much? Argentina 1991-2002",

Martín González-Rozada, (UTDT) y Alicia Menendez, (Princeton University). 